\title{
Groundwater control for construction in the Lambeth Group
}

\author{
M. Preene and T. O. L. Roberts
}

\section{Excavations in the Lambeth Group often encounter groundwater problems. This is related to the variable nature of the Lambeth Group soils and the presence of permeable water-bearing layers of sand, silt and gravel, where groundwater inflows can lead to instability. The permeability of the water-bearing layers can vary within a wide range. The pore water pressure and associated piezometric head in each layer can be difficult to predict, as the piezometric profile may diverge from the hydrostatic, under the influence of underdrainage from the Chalk Group and Thanet Sand Formation, which forms the lower aquifer beneath the Lambeth Group. Stability of excavations can be improved by using groundwater control techniques to reduce pore water pressures in permeable layers. Suitable methods, including active and passive pressure relief and underdrainage are discussed, and case histories presented.}

\section{NOTATION}

$D_{10} \quad 10 \%$ particle size of a soil sample

$k \quad$ coefficient of permeability

$k_{\mathrm{h}} \quad$ coefficient of permeability in the horizontal direction

$k_{\mathrm{v}} \quad$ coefficient of permeability in the vertical direction

\section{INTRODUCTION}

The soils of the Lambeth Group are often encountered during construction of deep basements or tunnels, shafts and piles for infrastructure projects in London and the south-east of England. Permeable water-bearing layers may cause problems during construction, resulting from groundwater inflows, instability or uplift and base heave due to unrelieved pore water pressures. A variety of construction expedients can be used to deal with such conditions. This paper will outline how pumped well and passive well systems can be used to control groundwater and avoid these problems. Case histories are presented and recommendations made for suitable groundwater control techniques.

\section{GROUNDWATER PROBLEMS IN THE LAMBETH GROUP}

The nature of the three formations (Woolwich, Reading and Upnor) making up the Lambeth Group are well known, ${ }^{1}$ and engineering problems in these soils have recently been reviewed. ${ }^{2}$ All three formations are potentially water-bearing, and whereas the Upnor Formation is described as consisting of sand and pebble beds, the Woolwich Formation and Reading Formation consist predominantly of clay but contain variable layers and lenses of fine-grained sands and silts. The soils of the Lambeth Group often exhibit considerable heterogeneity and anisotropy; these two factors particularly affect the prediction and control of groundwater flow for construction projects.

Excavations into the Lambeth Group have often proved difficult, with the fine-grained sands and silts proving prone to instability-conditions known colloquially as 'running', 'boiling' or 'cowbelly'; Ferguson et al. ${ }^{3}$ describe tunnelling in these soils as 'challenging'. However described, the problem is clear. Positive pore water pressures in relatively permeable pockets, layers and lenses of sand and silt reduce effective stress to effectively zero when exposed at the face of an excavation: instability is the natural result. The practical problem of dealing with such unstable materials is even worse if working in the confined spaces of tunnel headings or shafts. Brunel's original tunnel beneath the Thames at Rotherhythe had to fight its way through these soils, ${ }^{4}$ and difficulties were also encountered on other tunnels. ${ }^{5,6}$

The following sections will discuss the hydrogeology of the Lambeth Group relevant to groundwater control, and then suitable methods of groundwater control will be presented.

\section{HYDROGEOLOGY OF THE LAMBETH GROUP}

The hydrogeology of the London Basin is conventionally described in terms of two principal aquifers (the upper and lower aquifers), which in much of central and west London are separated by an aquiclude.

The upper aquifer consists of the Thames Gravels, and the lower aquifer consists of the Chalk Group, Thanet Sand Formation and any significant permeable zones at the bottom of the Lambeth Group. The aquiclude consists of the London Clay Formation and the clays of the upper parts of the Lambeth Group. Over much of central London piezometric levels in the lower aquifer have been lowered (in some areas to below the aquiclude) by the effects of water supply abstraction in the past. Current reduced levels of abstraction have resulted in a general and continuing rise in piezometric level in the lower aquifer. 
This model implies that the Upnor Formation (the basal unit of the Lambeth Group) is in hydraulic continuity with the lower aquifer, and will have similar piezometric levels to those of that aquifer. However, the silt and sand layers in the Woolwich and Reading Formations are contained within the predominantly clay aquiclude, which in many areas is being underdrained by the lower aquifer.

The low vertical permeability of the clay units means that underdrainage will be incomplete, so piezometric levels in the silt and sand layers may be significantly higher than in the lower aquifer, while still being lower than their original piezometric level, which is typically assumed to follow a hydrostatic profile (Fig. 1). Also, any further reductions of piezometric level in the lower aquifer (for example from the operation of a deepwell dewatering system) may have little or no effect on pore water pressures in sand and silt layers in the Woolwich and Reading Formations in the short term (unless vertical drains are introduced as part of the underdrainage method). Factors affecting possible piezometric profiles are complex. $^{2,7}$

The range of permeability that can be expected from all units of the Lambeth Group is very wide, perhaps $1 \times 10^{-4}$ to $1 \times 10^{-10} \mathrm{~m} / \mathrm{s}^{2}$ The water-bearing layers within the Lambeth Group that give rise to problems of groundwater-induced instability generally fall within a narrower range. Such soils are of moderate permeability, with permeability of these fine sand or silt layers typically in the range $5 \times 10^{-5}$ to $1 \times 10^{-7} \mathrm{~m} / \mathrm{s}$. However, considerable variations in permeability may occur locally and, moreover, problems with in situ tests and sampling of these soils can make accurate permeability assessment difficult. This is illustrated by the data of Table 1, which shows the wide range of values measured in the field, estimated from samples, or used in modelling studies.

It is important to remember that the upper aquifer/aquiclude/ lower aquifer model is a generalisation, and locally may be a poor approximation to actual conditions. Simpson et al. ${ }^{7}$ describe geological features including scour hollows in the London Clay Formation that may result in soils of the Lambeth Group being in hydraulic connection with the upper aquifer, or the lower aquifer, or both. The presence of such conditions at a site could cause severe problems for construction and groundwater control.

\section{GROUNDWATER CONTROL METHODS}

It is interesting to contrast available case records of groundwater control projects in the upper aquifer (Thames Gravels) and lower aquifer (Thanet Sand Formation and Chalk Group) with experience in the Lambeth Group.

The upper aquifer is generally of high permeability, and has been routinely dewatered by sump pumping, wellpoints or deepwells. ${ }^{11,12}$ Pumped deepwells have been successfully used in the lower aquifer, generally pumping from the chalk in preference to the sands, owing to the difficulties of constructing wells of sufficient yield in the Thanet Sand Formation. ${ }^{13,14}$

There are relatively few documented case records of groundwater control in the water-bearing horizons of the Lambeth Group. This is possibly a reflection of the relative difficulty of such work, in contrast with groundwater control in the upper and lower aquifers. A number of case records will be presented in this paper, based on the authors' experience, and from published records.

\subsection{Pressure relief for basement, shaft and cofferdam construction} The predominantly clayey nature of the Woolwich Formation and Reading Formation means that excavation in these soils may not encounter significant 


\begin{tabular}{|c|c|c|c|}
\hline Location & Details & & Source \\
\hline \multirow{3}{*}{$\begin{array}{l}\text { London } \\
\text { Docklands }\end{array}$} & Upper beds of Lambeth Group & & Ferguson et al. $^{3}$ \\
\hline & $\begin{array}{l}\text { Coefficient of permeability (falling head tests) } \\
\text { Coefficient of permeability (pumping tests) } \\
\text { Lower beds of Lambeth Group }\end{array}$ & $\begin{array}{l}8.1 \times 10^{-9} \text { to } 3.3 \times 10^{-4} \mathrm{~m} / \mathrm{s} \\
1.2 \times 10^{-7} \text { to } 1.3 \times 10^{-5} \mathrm{~m} / \mathrm{s}\end{array}$ & \\
\hline & $\begin{array}{l}\text { Coefficient of permeability (falling head tests) } \\
\text { Coefficient of permeability (pumping tests) }\end{array}$ & $\begin{array}{l}2.0 \times 10^{-7} \text { to } 2.6 \times 10^{-4} \mathrm{~m} / \mathrm{s} \\
3.0 \times 10^{-6} \text { to } 4.9 \times 10^{-6} \mathrm{~m} / \mathrm{s}\end{array}$ & \\
\hline \multirow[t]{2}{*}{ Uxbridge } & $\begin{array}{l}\text { In situ tests in boreholes and piezometers (six tests) } \\
\text { Inferred from particle size data (using Hazen's rule) (five } \\
\text { samples) }\end{array}$ & $\begin{array}{l}3.2 \times 10^{-6} \text { to } 2.3 \times 10^{-5} \mathrm{~m} / \mathrm{s} \\
1.0 \times 10^{-10} \text { to } 1.3 \times 10^{-8} \mathrm{~m} / \mathrm{s}\end{array}$ & Preene and Powrie ${ }^{8}$ \\
\hline & $\begin{array}{l}\text { Back-calculated from wellpoint trial (total flow from } 10 \\
\text { wellpoints } 1.3 \mathrm{I} / \mathrm{s} \text { for } 6.8 \mathrm{~m} \text { drawdown) }\end{array}$ & $3.9 \times 10^{-5} \mathrm{~m} / \mathrm{s}$ & \\
\hline \multirow{2}{*}{$\begin{array}{l}\text { London } \\
\text { Docklands }\end{array}$} & In situ tests in boreholes and piezometers (II tests) & $4.0 \times 10^{-8}$ to $7.0 \times 10^{-6} \mathrm{~m} / \mathrm{s}$ & Preene and Powrie ${ }^{8}$ \\
\hline & $\begin{array}{l}\text { Inferred from particle size data (using Hazen's rule) } \\
\text { (23 samples) } \\
\text { Test well yielded a flow of } 0.25 \mathrm{l} / \mathrm{s} \text { for } 18 \mathrm{~m} \text { drawdown in well }\end{array}$ & $4.0 \times 10^{-6}$ to $3.2 \times 10^{-4} \mathrm{~m} / \mathrm{s}$ & \\
\hline \multirow[t]{2}{*}{$\begin{array}{l}\text { London } \\
\text { Docklands }\end{array}$} & $\begin{array}{l}\text { Permeability values used in computer model of London } \\
\text { Docklands }\end{array}$ & & Howland et al. ${ }^{9}$ \\
\hline & $\begin{array}{l}\text { Horizontal permeability, } k_{\mathrm{h}} \\
\text { Vertical permeability, } k_{\mathrm{v}}\end{array}$ & $\begin{array}{l}1.2 \times 10^{-6} \text { to } 1.2 \times 10^{-5} \mathrm{~m} / \mathrm{s} \\
2.3 \times 10^{-8} \text { to } 2.3 \times 10^{-6} \mathrm{~m} / \mathrm{s}\end{array}$ & \\
\hline
\end{tabular}

groundwater inflows. However, where deep structures are constructed in these soils, the presence of water-bearing layers at depth beneath the base of the excavation can result in a risk of 'base heave'.

Base heave occurs when an excavation is taken down in lowpermeability soils where a permeable stratum or layer beneath the excavation has a piezometric level significantly above excavation formation level. As the excavation is deepened and approaches the permeable layer there will come a point when the weight of clay below formation level (and the shearing resistance of the clay) is insufficient to resist the piezometric pressure in the water-bearing layer. If this occurs the base of the excavation will move bodily upwards or 'heave' (Fig. 2). At best this will compromise the formation bearing properties, and at worst can lead to inundation and collapse of the excavation.

Base heave can be avoided if the pore water pressures and corresponding piezometric level are lowered in water-bearing layers beneath the excavation. Designing such pressure relief systems in the Lambeth Group can be complex because of the difficulty of identifying water-bearing layers and of determining the corresponding piezometric levels at the site investigation stage. The depth and thickness of the permeable layers may be erratic and are likely to vary significantly, even between closely spaced boreholes. The pore water pressures at a given depth in the Lambeth Group can be difficult to predict (because of the effect of underdrainage of the lower aquifer), which complicates interpretation of drilling water strikes and piezometer readings.

Systems to prevent base heave by reduction of pore water pressures can be of either the pumped or passive (unpumped) type.

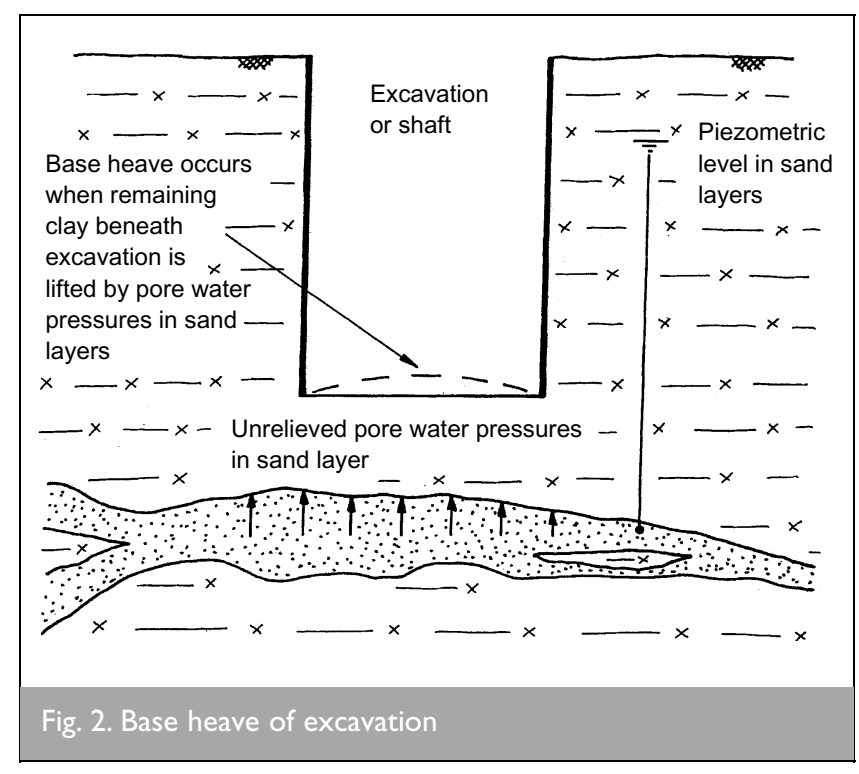

4.1.1. Passive pressure relief. Passive systems involve drilling vertical relief wells (either gravel-filled or with screens and liners) within the excavation itself. As the excavation proceeds below the original piezometric level the relief wells form vertical pathways, allowing water to flow into the excavation in a controlled way and thereby reducing pore water pressures and avoiding base heave (Fig. 3). Yuan and Foulds ${ }^{15}$ describe such a passive relief well system used during construction of the foundations for London's Millennium Bridge. The water flowing from the relief wells has to be removed by sump pumping, and in some soil types this can cause problems for the construction works owing to the space taken up by sumps, pumps and pipe work. However, in the Woolwich Formation 


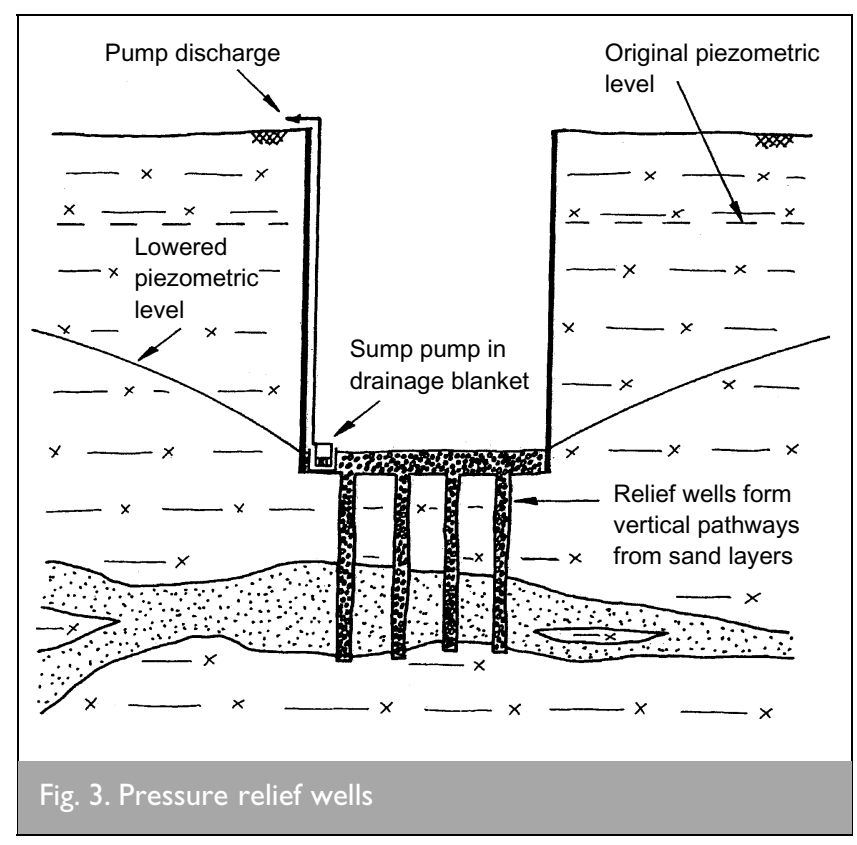

and Reading Formation typical inflows from passive relief wells are relatively modest, and often do not require extensive pump capacity; this makes the passive relief well method suitable for wide application in the Lambeth Group.

4.1.2. Pumped pressure relief. When active or pumped well pore pressure reduction systems are used, the wells are often located immediately outside the excavation. This approach can be illustrated by a case history where a deep basement was constructed for a new development in Uxbridge. Ground conditions were Thames Gravels over the Reading Formation, underlain by the Upnor Formation and Upper Chalk Formation (the Thanet Sand Formation being absent) (Fig. 4). The excavation penetrated into the clays of the Reading Formation to approximately $5 \mathrm{~m}$ below the piezometric levels indicated from the site investigation. A cut-off wall was used to exclude groundwater in the gravels of the upper aquifer, water trapped within the excavation being removed by sump pumping.
The Upper Chalk and Upnor Formations were at sufficient depth not to require pressure relief. However, boreholes indicated a zone a few metres below final formation level consisting of one or more layers of silty sand and silt with a piezometric head $5 \mathrm{~m}$ above final formation level. If the piezometric level in that zone was not reduced then base heave would probably have occurred when total stress was reduced by excavation. Because the permeable zone was at shallow depth, pumped wellpoints were used to reduce the piezometric level, to ensure that factors of safety against base heave stayed within acceptable limits. Piezometric levels in the superficial gravels and the deeper Upper Chalk and Upnor Formations were not affected by pumping. This suggests that the very low vertical permeability of the Lambeth Group clays prevented the drawdown in the permeable layers from having any impact on the more permeable upper and lower aquifers.

For a similar project near Windsor excavation was carried out to a depth of $7 \mathrm{~m}$ below ground level ( $5 \mathrm{~m}$ below initial piezometric levels). The groundwater in the superficial river gravels was excluded using sheet piles and a slurry wall, and the clays of the Reading Formation were exposed in the base of the excavation. Significant base heave was evident over part of the exposed formation soon after the dig was completed. A subsequent borehole investigation identified unrelieved pore water pressures in silt and sand lenses in the Reading Formation as the likely cause of the heave. Installation of a pumped well system reduced these pressures and allowed the project to be completed. The system consisted of four $15 \mathrm{~m}$ deepwells; total flow rate was less than $1 \mathrm{l} / \mathrm{s}$.

\subsection{Underdrainage to the lower aquifer}

An alternative approach to lowering pore water pressures in water-bearing layers is to use vertical drains (typically sand drains) to connect these layers to the more permeable lower aquifer. Provided the piezometric level in the lower aquifer is depressed (either by local dewatering wells or by the regional lowering due to historic pumping), vertical downward drainage will occur from the Lambeth Group, reducing pore water pressures. This is the approach used to prevent base heave in the Limehouse Link tunnel in east London. ${ }^{16}$ Deepwells were used to lower piezometric levels in the lower aquifer, and a grid of vertical drains was installed between the diaphragm walls of the cutand-cover tunnel, thus allowing initial high pore water pressures to bleed off into the lower aquifer (Fig. 5).

\subsection{Wellpoints drilled from tunnels for tunnel enlargements and cross- passages}

Tunnels in the Lambeth Group can present their own challenges. Morgan and Bubbers ${ }^{6}$ describe how tunnel drives for the London Underground Victoria Line at Euston Station encountered 


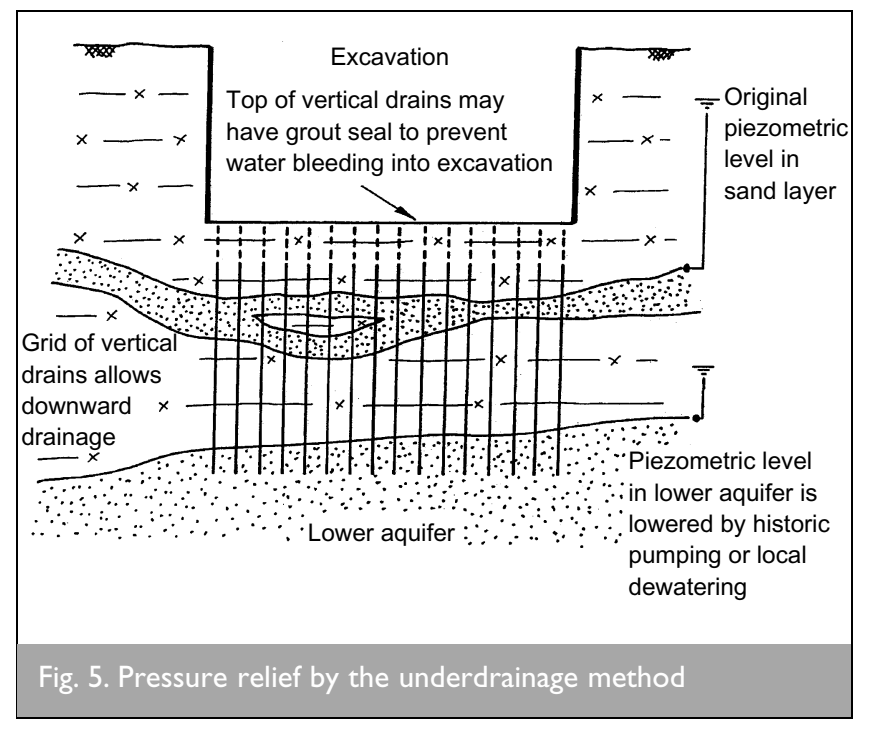

local problems due to water-bearing silty sand within the clays of the Lambeth Group. In some locations wellpoints were put down from tunnel passages, but, where only a thin sand layer was present, tunnel construction sometimes isolated the wellpoints from part of the sand layer, causing water pressures to build up on one side of the tunnel (Fig. 6). In such cases groundwater abstraction points were needed on both sides of the tunnel.

One section of tunnelling was stopped owing to an inflow of silty sand and water. Compressed air working was not effective at that location; following application of air pressure water inflows reappeared after a short time, and further increases in air pressure stopped inflows only temporarily. This is a classic problem in confined permeable layers of limited extent: the initial application of air pressure drives the water from the face, but because the permeable zone is finite the water has nowhere go. A vicious circle results, with application of air pressure raising the water pressure in the sand layer by a corresponding amount. The differential pressure is unchanged and inflows persist. On this occasion work was progressed without compressed air by driving a pilot tunnel ahead, from which wellpoints were drilled to depressurise the sand layer. An alternative approach, combining compressed air and

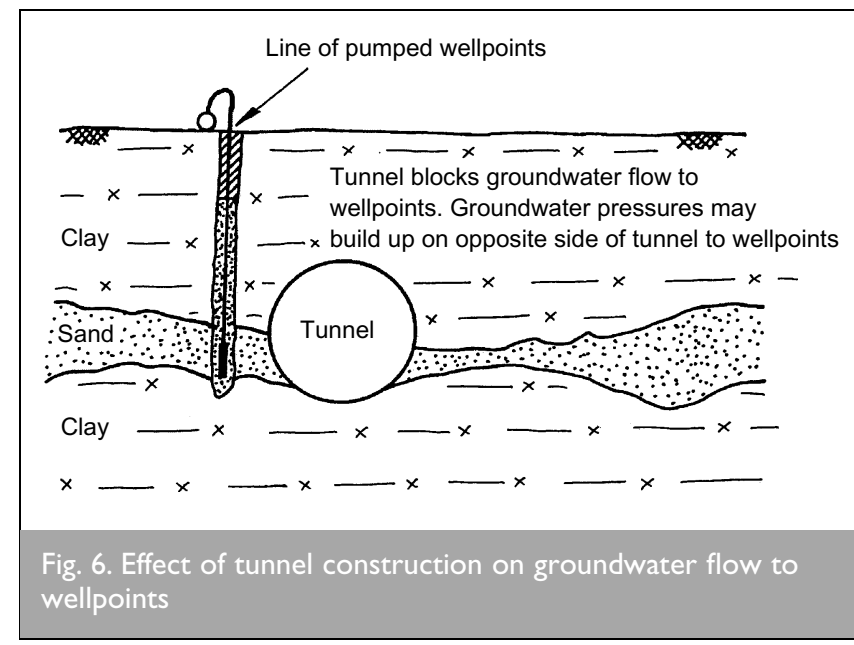

wellpoints, is to install the wellpoints into the sand layer from the tunnel face and connect them to discharge to free air outside the airlock. This provides a route for drainage of the sand layer as air pressure is applied to the face.

Pumped wellpoint systems drilled from tunnels have been used to control pore water pressures in specific sand layers within the Woolwich and Reading Formations in east London. Twin running tunnels were constructed using full-face tunnel-boring machines without the need for groundwater control. However, it was necessary to construct a cross-passage through stiff clay, but where a sand lens (up to $1 \mathrm{~m}$ thick, with an excess piezometric head of $20 \mathrm{~m}$ above tunnel invert) was found to be present just below the tunnel axis. To avoid the use of compressed air, a series of wellpoints were drilled out from the running tunnels (Fig. 7) and successfully controlled pore water pressures in the sand layer. Piezometer monitoring indicated that the completed tunnels acted as groundwater barriers in the sand lens, with the result that wellpoints were needed on both sides of the tunnel to control differential pressures. Final excavation for the cross-passages was not without its problems: inflows of residual water from the sand layer caused some minor instability locally at the sand-clay interface.

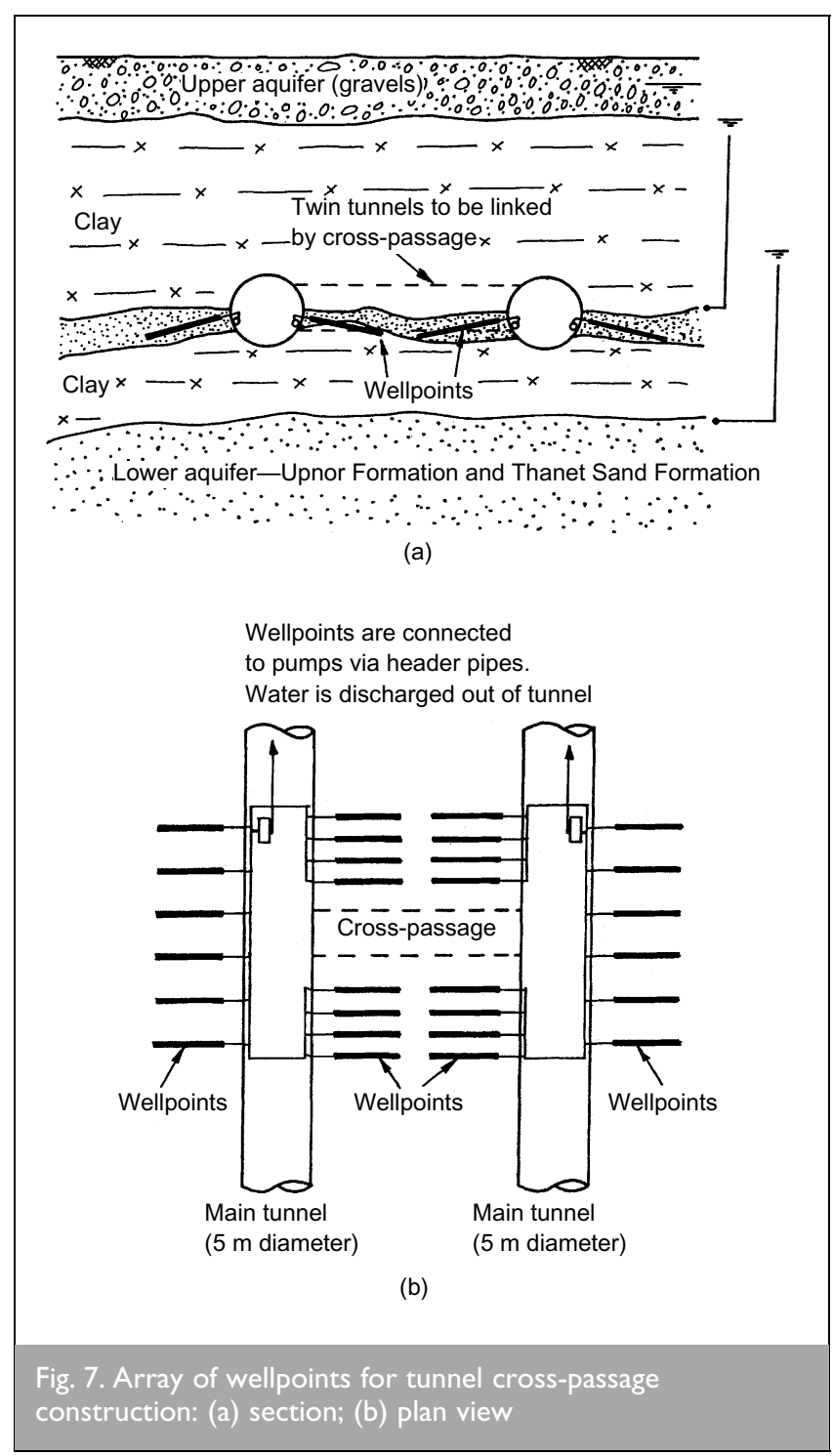




\section{CONCLUSIONS}

The case records show that both pumped and passive groundwater control systems can be used in water-bearing zones within the Lambeth Group. Because of the generally low to moderate permeability of these soils, the aim of a groundwater control system should be to depressurise permeable layers to improve stability, rather than to literally 'dewater' or dry out the soils. The five main methods of pumped groundwater control (sump pumping, passive relief wells, wellpoints, deepwells and ejector wells) are described in detail by Cashman and Preene, ${ }^{17}$ where applications to tunnel and shaft construction are also given. However, the nature of the Lambeth Group will restrict possible applications of each method: Table 2 highlights the suitability of each method for application in the Lambeth Group.
Even when groundwater control measures are successful in reducing pore water pressures in water-bearing silt and sand layers, excavations through these soils may still encounter localised inflows of water. These inflows result from the socalled 'residual water', which almost always remains in those layers, even following depressurisation. Because the driving groundwater pressure has been removed, these inflows are usually modest. However, localised instability may result, especially at the interface between the bottom of the waterbearing layer and the underlying clay. Inflows of residual water are typically managed by the use of sand bags, trench sheets, timbering of exposed faces, or other construction expedients appropriate to the excavation geometry and the available space.

The hydrogeological background suggests that in many cases

\begin{tabular}{ll} 
Method & Depth limits \\
\hline $\begin{array}{l}\text { Sump } \\
\text { pumping }\end{array}$ & $\begin{array}{l}\text { Drawdown limited by depth of sump, so } \\
\text { drawdowns of more than a few metres ar } \\
\text { rarely achieved. }\end{array}$
\end{tabular}

Passive relief Drawdown limited only by the depth of wells excavation and soil stratification.

Wellpoints Drawdown is limited to 5 or $6 \mathrm{~m}$ below the pump when used to depressurise layers below an excavation or tunnel. This limit may not apply when used to depressurise soils around or above a tunnel.

Deepwells Drawdown limited only by depth of well and soil stratification.

Ejector wells Drawdown limited to about 30-50 m below supply pump level owing to practical considerations.

\section{Comments}

Not ideally suited to the fine-grained soils of the Lambeth Group because (unless adequate filters can be provided) fine particles may be drawn from the soil, leading to possible erosion and instability. However, sump pumping is sometimes used as a stopgap measure to deal with local small-scale inflows of residual water in tunnels or shafts, or where the use of more complex systems may not be practicable.

Can be used for excavations through predominantly clay horizons, where water-bearing layers or lenses are anticipated below formation level. Forms a vertical pathway allowing water to flow upwards to the excavation, thereby reducing pore water pressures. The water entering the excavation must be directed to a sump and then pumped away. Best suited to cases where the water-bearing layers are believed to be relatively thin and inflows will be small. More extensive layers can give substantial inflows, and the collection and disposal of large volumes of water can be an impediment to the construction works.

Can be used in sand or pebble beds installed either vertically (or inclined) from the surface or radially out from tunnels or shafts. May be pumped by a conventional wellpoint pump (either at ground level or within the tunnel or shaft), or-when installed out from a tunnel-may simply be left to flow freely and bleed off pore water pressures (the water from the wellpoints being disposed of via the tunnel drainage system). May be of limited effectiveness in reducing pore water pressures in very silty layers: in such cases an ejector well system may be appropriate.

Can be used in sand or pebble beds, generally installed vertically from the surface. Pumped by electric submersible pumps in each well; the systems may be difficult to operate at low flow rates $(<\mathrm{I} \mathrm{I} / \mathrm{s}$ per well). This method is best suited to situations where the permeable beds are anticipated to be relatively thick and laterally extensive, and where total flow rates may be significant. In some cases vacuum may be applied to the well to attempt to improve yield and drawdown.

Can be used in silt, sand or pebble beds installed either vertically (or inclined) from the surface or radially out from tunnels or shafts. Pumped by a high-pressure supply pump located either at ground level or within the tunnel or shaft. The high vacuum (up to 0.95 bar) that can be generated in the well makes this system ideally suited for depressurisation of silty sand or silt layers. The flow rate that can be pumped by a single ejector is generally limited to $30-60 \mathrm{I} / \mathrm{min}$; as a result, ejectors may not have sufficient capacity for depressurisation of sand or pebble layers in continuity with the upper or lower aquifers, unless augmented by a deepwell system. 
silt and sand layers within the Woolwich Formation and Reading Formation may be largely isolated from the upper and lower aquifers. Piezometric levels may be significantly higher than those in the lower aquifer. During site investigation piezometer installation and monitoring is essential, and should be targeted to any permeable zones (silt, sand or gravel) revealed during boring. Flow rates from pressure relief systems are generally anticipated to be low (less than $10 \mathrm{l} / \mathrm{s}$ for all but the largest systems). However, if a scour hollow or other geological feature allows these layers to be linked to one of the aquifers, groundwater control may be much more difficult. This issue should be addressed during the site investigation.

The Upnor Formation (and any significant sand layers at the base of the other formations) may be in hydraulic continuity with the underlying lower aquifer. Successful depressurisation of these strata must, in effect, depressurise the top of the lower aquifer, probably by pumping from the Thanet Sand Formation and Chalk Group. Accordingly, the total flow rate may be much greater than for direct pressure relief of the Woolwich Formation and Reading Formation.

\section{REFERENCES}

1. SUMBLER M. G. British Regional Geology: London and the Thames Valley, 4th edn. HMSO, London, 1996.

2. Hight D. W., Ellison R. A. and PAGE D. P. Engineering in the Lambeth Group. Construction Industry Research and Information Association, London, 2001, CIRIA Funders Report CP/83.

3. Ferguson P. A. S., RunAcres A. J. and Hill N. A. London's Docklands: ground conditions and tunnelling methods. Proceedings of the Institution of Civil Engineers, Part 1, 1991, 90, 1179-1201.

4. Skempton A. W. and Chrimes M. M. Thames Tunnel: geology, site investigation and geotechnical problems. Géotechnique, 1994, 44, No. 2, 191-206.

5. BROMEHEAD C. E. N. Memoirs of the Geological Survey of England and Wales. The Geology of North London. HMSO, London, 1925.

6. Morgan H. D. and BubBers B. L. Station construction. In
The Victoria Line (Follenfant H. G. et al. (eds)). Proceedings of the Institution of Civil Engineers, 1969, Supplementary Volume, 453-475.

7. Simpson B., Blower T., CRAig R. N. and WiLKINSON W. B. The Engineering Implications of Rising Groundwater Levels in the Deep Aquifer Beneath London. Construction Industry Research and Information Association, London, 1989, Special Publication 69.

8. PREENe M. and Powrie W. Steady-state performance of construction dewatering systems in fine soils. Géotechnique, 1993, 43, No. 2, 191-206.

9. Howland A. F., Rushton K. R., SutTon S. E. and Tomlinson L. M. A hydrogeological model for London Docklands. In Groundwater Problems in Urban Areas (WILKINSON W. B. (ed.)). Thomas Telford, London, 1994, pp. 76-92.

10. Preene M., Roberts T. O. L., Powrie W. and Dyer M. R. Groundwater Control: Design and Practice. Construction Industry Research and Information Association, London, 2000, Report C515.

11. HaRding H. J. B. The Principles and Practice of Groundwater Lowering. Institution of Civil Engineers, Southern Association, 1946.

12. Glossop R. and CollingRidge V. H. Notes on groundwater lowering by means of filter wells. Proceedings of the $2 n d$ International Conference on Soil Mechanics and Foundation Engineering, Rotterdam, 1948, 2, 320-322.

13. BoARDMAN M. F. Discussion: Engineering solutions to groundwater problems. In Groundwater Problems in Urban Areas (WILKInSON W. B. (ed.)). Thomas Telford, London, 1994, pp. $446-450$.

14. LinNeY L. F. and Withers A. D. Dewatering the Thanet beds in SE London: three case histories. Quarterly Journal of Engineering Geology, 1998, 31, 115-122.

15. YUAN F. and FouLDS G. K. Pressure relief for the London Millennium Bridge. Ground Engineering, 2000, 33, No. 11, 42-46.

16. SteVenson M. C. and De MooR E. K. Limehouse Link cutand-cover tunnel: design and performance. Proceedings of the 13th International Conference on Soil Mechanics and Foundation Engineering, New Delhi, 1994, 2, 887-890.

17. CASHMAN P. M. and PREENE M. Groundwater Lowering in Construction: A Practical Guide. Spon, London, 2001.

Please email, fax or post your discussion contributions to the secretary by I April 2003: email: mary.henderson@ice.org.uk; fax: +44 (0)20 7799 1325; or post to Mary Henderson, Journals Department, Institution of Civil Engineers, 1-7 Great George Street, London SWIP 3AA. 